\title{
Pengaruh COVID-19 Terhadap Kegiatan Ekspor Impor di Indonesia
}

\author{
Diva Permata Tri Putri ${ }^{{ }^{*}}$, Eva Wina Aprielya Damayanti ${ }^{\text {b }}$, Intan Sianturi ${ }^{\mathrm{c}}$ \\ a,b,c Politeknik Pelayaran Surabaya \\ a*Email: divaptp354@gmail.com
}

\begin{abstract}
ABSTRAK
Pandemi Covid-19 berakibat fatal bagi perkembangan ekonomi dunia, salah satunya terjadi di Indonesia. Peraturan pemerintah mewajibkan masyarakat untuk menerapkan protokol kesehatan yang wajib dipatuhi yaitu dengan pembatasan sosial (social distancing) yang menyebabkan para pedagang terhambat dalam proses kegiatan jual beli. Tujuan penelitian ini adalah menganalisis dampak Covid-19 terhadap kegiatan ekspor impor di Indonesia. Metode penelitian ini menggunakan metode desk study yaitu metode pengumpulan data yang berasal dari data sekunder yang diperoleh dari BPS tahun 2020. Hasil penelitian menunjukkan bahwa Covid-19 memiliki beberapa dampak antara lain: (1) Penurunan nilai impor di Indonesia terbesar dialami pada Februari 2020 dan Mei 2020; (2) Pengurusan dokumen harus membutuhkan waktu lebih lama dikarenakan dengan adanya pandemi ini dan seluruh kegiatan ekspor impor harus berpedoman kepada protokol kesehatan yang wajib dijalankan; (3) Keterlambatan penanganan kapal di pelabuhan (kapal delay), yang akan berdampak pada keterlambatan barang sampai ke tangan pemilik barang (importir) yang menyebabkan importir juga harus menyiapkan biaya lebih untuk mengimpor barangnya.
\end{abstract}

Kata Kunci: covid-19, dampak, ekspor impor

\section{ABSTRAK}

The Covid-19 pandemic has fatal consequences for the world economy, one of which occurred in Indonesia. Government regulations require the public to apply health protocols that must be obeyed, namely social distancing which causes traders to be hampered in the process of buying and selling activities. The purpose of this study is to analyze the impact of Covid-19 on exportimport activities in Indonesia. This research method uses the desk study method, namely the collection of data sourced from secondary data obtained from BPS in 2020. The results show that: Covid-19 has had an impact including: (1) The largest decline in the value of imports in Indonesia was experienced in February 2020 and May 2020; (2) Document processing must take longer due to this pandemic and all import-export activities must be guided by health protocols that must be carried out; (3) Delay in handling the ship at the port (ship delay), which will have an impact on the delay of the goods arriving at the hands of the owner of the goods (importer) which causes the importer to also have to prepare more costs for importing the goods.

Keywords: covid-19, impact, eksport import

\section{PENDAHULUAN}

Wuhan China merupakan kota ditemukannya virus corona pertama kali. Sejak wabah muncul di Wuhan, Tiongkok pada Desember 2019, manusia telah menemukan jenis baru virus corona, yang kemudian diberi nama https://doi.org/10.46484/db.v2i2.271
Severe Acute RespiratorySyndrome Coronavirus 2 (SARS-COV2), dan menyebabkan penyakit Corona virus Disease 2019 (COVID-19). Pada mulanya penyebabnya adalah kelelawar dan ditularkan ke manusia melalui hewan lain yang belum diketahui 
identitasnya (Singhal, 2020). Jumlah yang tertular COVID-19 dan betapa luasnya penyebarannya sudah mengalahkan SARS dan MERS (Hu, Guo, Zhou, \& Shi, 2021) yang secara dramatis bisa merenggut nyawa (Shereen, Khan, Kazmi, Bashir, \& Siddque, 2020).

Seluruh dunia saat ini sedang menghadapi pandemi Virus Covid-19 yang terus menyebar. Virus ini ditetapkan oleh WHO sejak 30 Januari 2021 sebagai sebuah epidemi yang menjadi perhatian internasional (Guo, et al., 2020). Bahkan sudah menyebar hingga tahap gelombang kedua di tahun 2021 (Iftimie, et al., 2021). Pandemi ini memiliki dampak besar diberbagai sektor, salah satunya perekonomian negara. Ekspor dan impor adalah kegiatan penting bagi suatu negara. Dari kegiatan ekspor dan impor suatu negara akan mendapatkan pendapatan. Negara banyak yang memberlakukan lockdown sehingga berpengaruh pada kegiatan ekspor dan impor. Lockdown diperlukan untuk mengurangi kontak yang terjadi antara orang-orang sehingga bisa mengurangi jumlah yang tertular COVID-19 (Oraby, et al., 2021) yang memengaruhi kehidupan masyarakat seperti menganggur, isolasi sosial, dan juga kurangnya kebebasan beraktivitas (Brodeur, Clark, Fleche, \& Powdthavee, 2020) hingga mempengaruhi ekonomi secara global (Onyeaka, Anumudu, AlSharify, Egele-Godswill, \& Mbaegbu, 2021) termasuk ekspor dan impor yang sangat penting untuk memenuhi kebutuhan negara luar dan dalam negeri (Sultanuzzaman, Fan, Mohamued, Hossain, \& Islam, 2019).

Data statistik yang dikeluarkan oleh Badan Pusat Statistik (BPS) tahun 2020 menunjukkan bahwa pandemi Virus Covid-19 berdampak pula bagi kegiatan impor migas dan non migas di Indonesia pada periode Januari hingga periode Juni 2020. Pada waktu tersebut kegiatan impor khususnya sektor non migas mengalami fluktuasi, seperti yang dapat dilihat pada Gambar 1. Padahal, migas menyediakan hampir 60\% dari energi dunia (Kong, Dong, Shao, Wan, Tang, \& Liu, 2016).

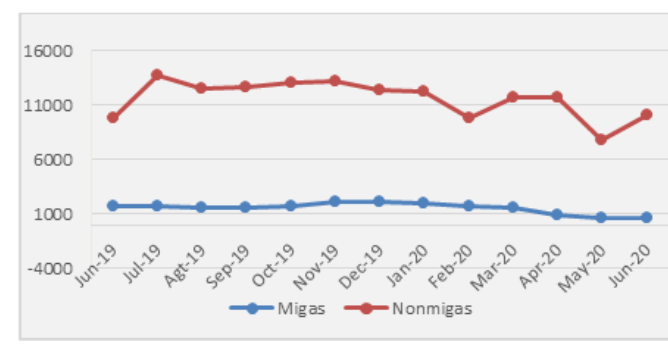

Gambar 1. Nilai Impor Migas dan Non Migas Sumber : BPS (2020)

Berdasarkan data BPS 2020 tentang nilai impor migas dan non migas pada Gambar 1 dinyatakan bahwa jumlah impor sektor migas lebih kecil jika dibandingkan dengan impor sektor non migas. Hal tersebut disebabkan oleh impor sektor migas berupa minyak mentah, hasil minyak, dan gas yang merupakan sumber daya alam dengan jumlah terbatas, sehingga jumlah yang diimpor kecil.

\section{METODE}

Metode penelitian yang digunakan adalah metode desk study. Metode desk study yaitu metode pengumpulan data dan informasi dengan pemeriksaan serta analisis menggunakan data sekunder, baik berupa dokumen internal/eksternal perusahaan, peraturan perundang-undangan yang terkait RSPO, laporan, data statistik, studi pustaka, peta-peta dan sebagainya.

Bentuk penelitian ini adalah deskriptif yang bertujuan untuk mengetahui berbagai dampak pada masa pandemi ini. Data yang digunakan dalam penelitian ini berasal dari data sekunder yang diperoleh dari data BPS tahun 2020.

\section{HASIL DAN PEMBAHASAN}

Data BPS 2020 tentang ketidakstabilan nilai impor pada Januari 2020 hingga Juni 2020 diakibatkan pandemi Covid-19. Desember 2019 nilai impor sebesar USD12.373,6 juta, sedangkan pada Januari 2020 nilai impor 
mengalami penurunan. Penurunan terbesar dialami pada Februari 2020 dan Mei 2020. Pada Februari 2020 penurunan terjadi karena banyak negara yang mengonfirmasi bahwa warga negaranya terinfeksi Covid-19, sehingga kegiatan impor maupun ekspor dibatasi. Hal tersebut dilakukan untuk mengurangi risiko penyebaran virus Covid-19.

BPS juga merilis nilai impor di sepuluh provinsi utama di Indonesia. Nilai impor tertinggi untuk Negara juta $(7,60 \%)$, Banten USD4.842,3 juta $(6,83 \%)$, Jawa Tengah USD4.515,3 juta $(6,37 \%)$, Sumatera Utara USD1.976,1 juta (2,79\%), Kalimantan Timur USD1.006,1 juta (1,42\%), Jawa Barat USD946,5 juta (1,34\%), Sulawesi Tengah USD913,5 juta (1,29\%), dan Sulawesi Tenggara USD783,9 juta $(1,11 \%)$. Provinsi lainnya memiliki nilai impor yang berada di bawah USD750 juta.

Perbedaan nilai impor sangat terlihat jelas pada Provinsi DKI

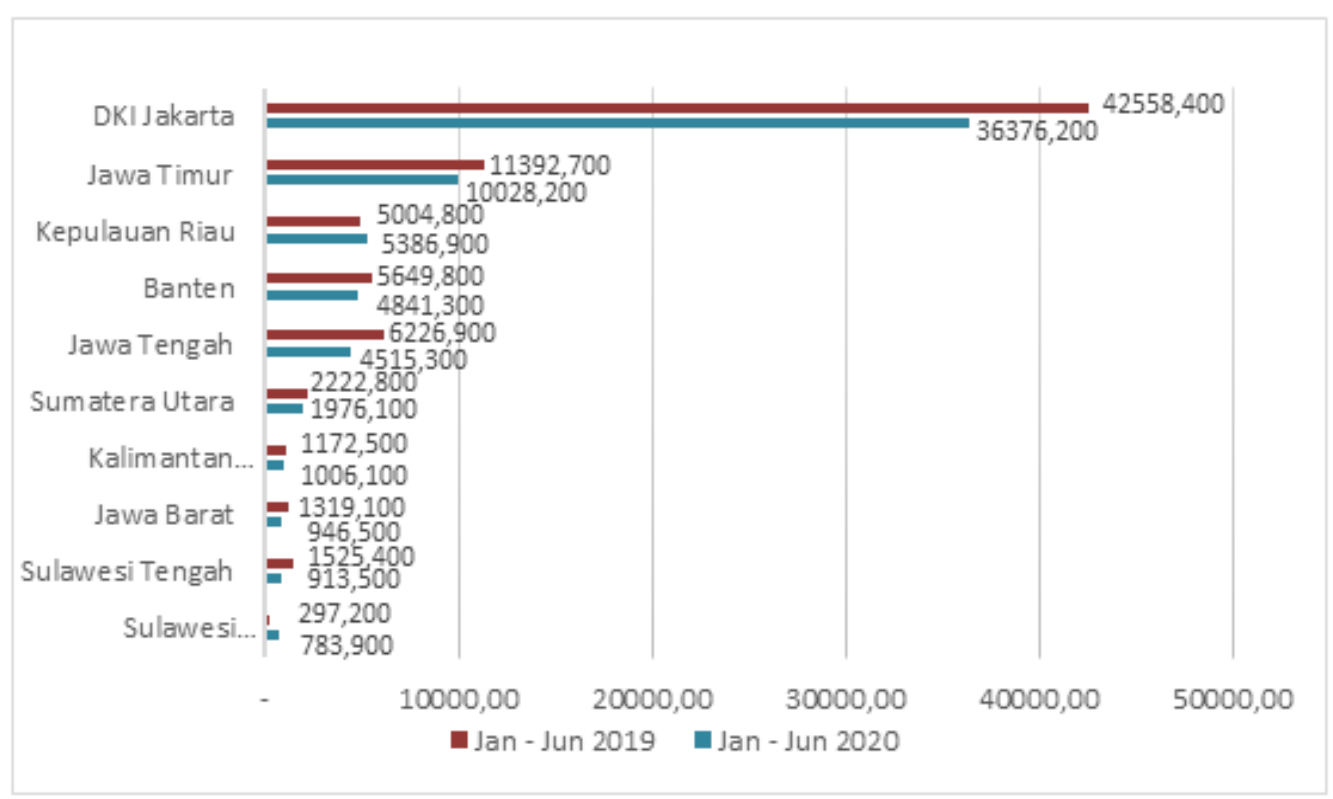

Gambar 2. Nilai Impor di Sepuluh Provinsi Utama Januari-Juni 2019 dan 2020 Sumber: BPS (2020)

Indonesia mulai Januari hingga Juni 2019 ditempati oleh Provinsi DKI Jakarta dengan nilai (USD42.558,4 juta). Posisi kedua ditempati oleh Jawa Timur (USD11.392,7 juta), selanjutnya Jawa Tengah, Banten, Kepulauan Riau, Sumatera Utara, Sulawesi Tengah, Jawa Barat, Kalimantan Timur, dan Sulawesi Tenggara. Selama Januari hingga Juni 2020 Provinsi DKI Jakarta masih menempati posisi pertama dengan nilai impor sebesar USD36.376,2 juta, dan memberikan konstribusi sebanyak $51,30 \%$ dari total impor Indonesia. Provinsi dengan nilai impor tertinggi kedua adalah Jawa Timur dengan nilai impor sebesar USD10.028,2 juta (14,14\%), diikuti oleh Provinsi Kepulauan Riau sebesar USD5.386,9
Jakarta, hal ini diakibatkan karena DKI Jakarta merupakan ibu kota Negara Indonesia. DKI Jakarta merupakan pusat persebaran barang-barang yang datang dari luar negeri. Selain itu, masyarakat atau penduduk ibu kota cenderung memiliki sifat yang lebih konsumtif, sehingga persebaran nilai impor di DKI Jakarta jauh lebih tinggi dibandingkan dengan provinsi lainnya.

Proses bongkar muat barang di pelabuhan dirasakan mengalami keterlambatan karena faktor cuaca. Meskipun demikian, secara keseluruhan, proses bongkar muat di sana berjalan lancar. Pengaruh cuaca dan tempat beaching (beaching point).

Tempat beaching (beaching point) dan cuaca sekitar kapal sangat 
memengaruhi proses sandar beaching seperti:

1. Tempat beaching bebatuan di pantai dapat membuat lambung kapal rusak.

2. Besarnya ombak sekitar kapal.

3. Kuat arus dan arah angin sangat berpengaruh terhadap proses beaching terutama di perairan dangkal.

4. Kedalaman perairan sekitar kapal.

Pada kegiatan ekspor impor human error menjadi faktor yang harus diantisipasi dalam kegiatan eksporimpor agar tidak terjadi kerugian baik di pihak eksportir maupun pihak importir. Di era pandemi covid 19 seperti sekarang ini dimana segala sesuatu yang kita lakukan harus berpedoman pada protokol kesehatan untuk mencegah penyebaran covid 19 kondisi ini telah memukul kegiatan perekonomian global, termasuk lalu lintas perdagangan internasional.

Terhambatnya kegiatan ekspor impor menyebabkan kenaikan harga sejumlah komoditas pangan dan penutupan sejumlah bisnis. Ketika bisnis kehilangan pendapatan, pengangguran cenderung meningkat tajam. Dampak ini akan terus terasa selama adanya pembatasan pergerakan orang dan kegiatan ekonomi, serta tergantung pada respons dari otoritasotoritas keuangan nasional.

Dengan demikian tidak bisa dipungkiri akan terjadi banyak kesalahan disebabkan faktor manusia atau biasa disebut human error, dengan adanya pandemi ini kegiatan ekspor impor harus berpedoman protokol kesehatan yang membuat harus membutuhkan waktu lebih dalam pengurusan dokumen dan ditambah dengan pemeriksaan kesehatan baik swab maupun rapid test.

Pada pengurusan dokumen serta pemeriksaan kesehatan ini banyak terjadi kesalahpahaman akan syarat yang perlu disiapkan untuk berlabuh dan standarisasi kesehatan berlaku serta protokol yang wajib dijalankan karena akan sangat berbeda di era new normal seperti sekarang ini dan sebelumnya.

Baik pihak shipping dan pihak kepelabuhan yang berkaitan harus berkomunikasi agar tidak terjadi kesalahan yang akan berdampak pada keterlambatan barang ekspor dan impor.

Untuk itu seorang eksportir dan importir tidak hanya dituntut untuk mengerti masalah barang ekspor/impor juga dituntut keterampilannya dalam pengurusan dokumen dan penyelesaian transaksinya.

Kapal delay yaitu keterlambatan kapal untuk ditangani atau dilayani yang dapat disebabkan oleh banyak faktor. Kapal delay sangat berpengaruh pada kegiatan ekspor impor karena dengan adanya kapal delay akan terjadi keterlambatan sampainya barang ke pembeli atau importir yang akan berdampak pada kerugian pada pelaku bisnis baik eksportir maupun importir.

\begin{tabular}{cccc}
\multicolumn{2}{c}{ Keterlambatan terjadi yang } \\
disebabkan delay kapal akan
\end{tabular}
berpengaruh terhadap biaya yang semakin besar, karena semakin lama kapal berada di pelabuhan akan semakin besar biaya yang dikeluarkan. Keterlambatan delay kapal juga akan berpengaruh pada pendistribusian yang telat, jika barang tersebut mudah rusak/busuk maka semakin lama barang itu sampai untuk diolah atau didistribusikan dan akan semakin turun kualitasnya serta harga jualnya.

Di era kenormalan baru (pandemi COVID-19) seperti sekarang ini kapal delay tidak dapat dihindarkan lagi karena selain pengurusan dokumen untuk sandar di pelabuhan ditambah lagi dengan harus mematuhi protokol kesehatan untuk mencegah penyebaran covid 19 yang harus dipatuhi. Hal ini berdampak keterlambatan penanganan kapal di pelabuhan (kapal delay), yang akan berdampak pada keterlambatan barang sampai ke tangan pemilik barang (importir), dan importir juga harus menyiapkan biaya lebih untuk mengimpor barangnya. 


\section{SIMPULAN}

Berdasarkan analisis pengaruh COVID-19 terhadap kegiatan ekspor impor di Indonesia, dapat disimpulkan bahwa penurunan nilai impor di Indonesia paling besar dialami pada Februari 2020 dan Mei 2020. Pada Februari 2020 penurunan terjadi karena mulai banyak negara yang mengkonfirmasi bahwa warga negaranya terinfeksi Covid-19, sehingga kegiatan impor maupun ekspor dibatasi. Selama Januari hingga Juni 2020 Provinsi DKI Jakarta masih menempati posisi pertama dengan nilai impor sebesar USD36.376,2 juta, dan berperan sebanyak $51,30 \%$ dari total impor Indonesia. Perbedaan nilai impor sangat terlihat jelas pada Provinsi DKI Jakarta, hal ini diakibatkan karena DKI Jakarta merupakan ibu kota Negara Indonesia. DKI Jakarta merupakan pusat persebaran barang-barang yang datang dari luar negeri.

Pengurusan dokumen harus membutuhkan waktu lebih lama dikarenakan dengan adanya pandemi ini dan seluruh kegiatan ekspor impor harus berpedoman kepada protokol kesehatan yang wajib dijalankan karena akan sangat berbeda di era new normal seperti sekarang ini dan sebelumnya, baik pihak shipping dan pihak kepelabuhan yang berkaitan harus berkomunikasi agar tidak terjadi kesalahan yang akan berdampak pada keterlambatan barang ekspor dan impor. Dengan demikian tidak bisa dipungkiri akan terjadi banyak kesalahan disebabkan faktor manusia atau biasa disebut human error.

Keterlambatan penanganan kapal di pelabuhan (kapal delay), yang akan berdampak pada keterlambatan barang sampai ke tangan pemilik barang (importir), dan importir juga harus menyiapkan biaya lebih untuk mengimpor barangnya. Pengaruh COVID-19 juga memengaruhi kapal delay yaitu masalah pengurusan dokumen yang memakan waktu.

\section{DAFTAR PUSTAKA}

Brodeur, A., Clark, A. E., Fleche, S., \& Powdthavee, N. (2020). COVID19, lockdowns and well-being: Evidence from Google Trends. J Public Econ, Vol. 193(104346).

BPS. (2020). Buletin Statistik Perdagangan Luar Negeri Impor. [Ebook]. BPS RI.

https://www.bps.go.id/publication 12020/09/01/d6de4def78e261409e ce6edb/buletin-statistikperdagangan-luar-negeri-imporjuni-2020.htm

Guo, Y.-R., Cao, Q.-D., Hong, Z.-S., Tan, Y.-Y., Chen, S.-D., Jin, H.-J., et al. (2020). The origin, transmission and clinical therapies on coronavirus disease 2019 (COVID-19) outbreak - an update on the status. Military Medical Research, Vol. 7(11).

Hu, B., Guo, H., Zhou, P., \& Shi, Z.-L. (2021). Characteristics of SARSCoV-2 and COVID-19. Nature Reviews Microbiology volume 19, 141-154.

Iftimie, S., Lopez-Azcona, A., Vallverdu, I., Hernandez-Flix, S., de Febrer, G., Parra, S., et al. (2021). First and second waves of coronavirus disease-19: A comparative study in hospitalized patients in Reus, Spain. PLoS ONE 16(3).

Kong, Z.-Y., Dong, X.-X., Shao, Q., Wan, X., Tang, D.-L., \& Liu, G.-X. (2016). The potential of domestic production and imports of oil and gas in China: an energy return on investment perspective. Petroleum Science volume 13, 788-804.

Onyeaka, H., Anumudu, C. K., Al-Sharify, Z. T., Egele-Godswill, E., \& Mbaegbu, P. (2021). COVID-19 pandemic: A review of the global lockdown and its far-reaching effects. Science Progress, Vol. 104(2).

Oraby, T., Tyshenko, M., Maldonado, J., Vatcheva, K., Elsaadany, S., Alali, $\mathrm{W}$., et al. (2021). Modeling the effect of lockdown timing as a 
COVID-19 control measure in countries with differing social contacts. Scientific Reports, Vol. 11(3354).

Shereen, M. A., Khan, S., Kazmi, A., Bashir, N., \& Siddque, R. (2020). COVID19 infection: Emergence, transmission, and characteristics of human coronaviruses. Journal of Advanced Research, Vol. 24, 91-98.

Singhal, T. (2020). A Review of Coronavirus Disease-2019 (COVID-19). Indian J Pediatr, Vol. 87(4) , 281-286.

Sultanuzzaman, M. R., Fan, H., Mohamued, E. A., Hossain, M. I., \& Islam, M. A. (2019). Effects of export and technology on economic growth: Selected emerging Asian economies. Economic ResearchEkonomska Istraživanja, 32:1, 2515-2531. 